\title{
Genetic Risk
}

National Cancer Institute

\section{Source}

National Cancer Institute. Genetic Risk. NCI Thesaurus. Code C18808.

Risk of developing a disease based on a patients heredity 